DOE/䨌-0025

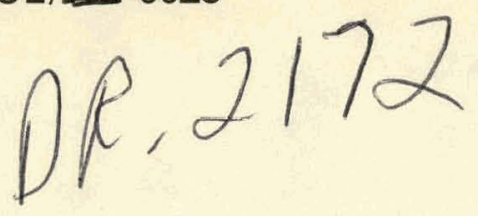

\title{
Proposed Standby Gasoline Rationing Plan Public Comments
}

December 1978

\section{U.S. Department of Energy}

Economic Regulatory Administration

Office of Regulations and Emergency Planning

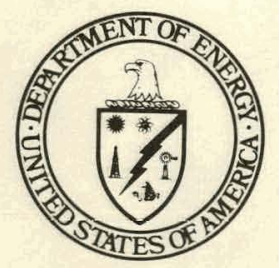




\section{DISCLAIMER}

This report was prepared as an account of work sponsored by an agency of the United States Government. Neither the United States Government nor any agency Thereof, nor any of their employees, makes any warranty, express or implied, or assumes any legal liability or responsibility for the accuracy, completeness, or usefulness of any information, apparatus, product, or process disclosed, or represents that its use would not infringe privately owned rights. Reference herein to any specific commercial product, process, or service by trade name, trademark, manufacturer, or otherwise does not necessarily constitute or imply its endorsement, recommendation, or favoring by the United States Government or any agency thereof. The views and opinions of authors expressed herein do not necessarily state or reflect those of the United States Government or any agency thereof. 


\section{DISCLAIMER}

Portions of this document may be illegible in electronic image products. Images are produced from the best available original document. 
Available from:

National Technical Information Service (NTIS) U.S. Department of Commerce 5285 Port Royal Road Springfield, Virginia 22161

Price: Printed copy: $\$ 5.25$ Microfiche: $\quad \$ 3.00$ 


\section{Proposed Standby Gasoline Rationing Plan}

Public Comments

December 1978

\section{U.S. Department of Energy}

Economic Regulatory Administration

Office of Regulations and Emergency Planning

Washington, D.C.
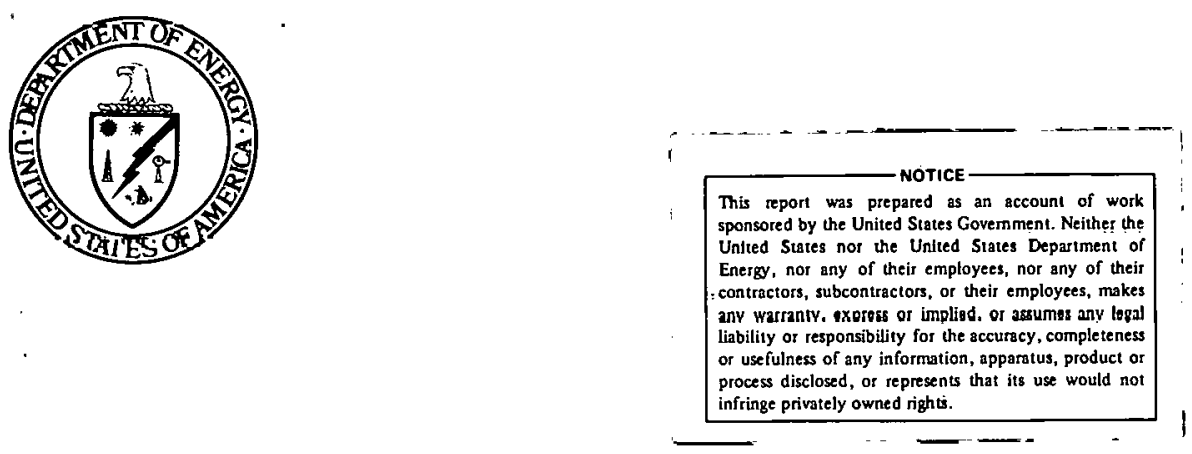
This report contains a summary of the comments received during the recent public comment period on the Department of Energy's Proposed Contingency Gasoline Rationing Plan.

The Proposed Plan was published in the Federal Register on June 28,1978 . The comment period officially closed on . October 3, 1978. 
TABLE OF CONTENTS

Page

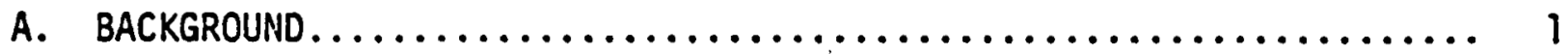

B. CLASSIFICATION METHODOLOGY AND STATISTICAL SUMMARY........... 6

C. PRESENTATION OF ISSUES RAISED BY RESPONDENTS $\ldots \ldots \ldots \ldots \ldots \ldots \ldots \ldots$

1. Introduction.................................. 10

2. AlTotment Issues................................... 11

2.1 The Basis for Firms' Allotments: Vehicle Registrations vs. Base Period Consumption.......................... 11

2.2 Priority and Designated Firms, and Special Circumstances. 12

2.3 Farmers................................ 17

2.4 Leased and Rental Vehicles....................... 18

2.5 The Basis for Private Individuals' Allotments: Vehicle Registrations vs. Drivers' Licenses........... 19

2.6 Recreational Vehicles (RVs)................... 21

2.7 Allotment Entitlements........................ 22

3. Coupon Related Issues......................... 23

3.1 Coupon Issuance and Ration Banking............... 23

3.2 The White Market.......................... 26

3.3 Coupon Denominations....................... 28

3.4 Expiration of Ration Documents.................. 29 
TABLE OF-CONTENTS (CONTINUED)

Page

4. State Issues................................... 30

4.1 Use of a State Adjustment Factor in Computing

Al lotments.................................... 30

4.2 State Ration Reserves (SRR) ..................... 32

4.3 State Funding............................. 34

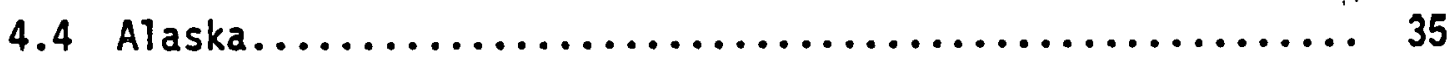

5. $0 i 1$ Industry Related Issues....................... 36

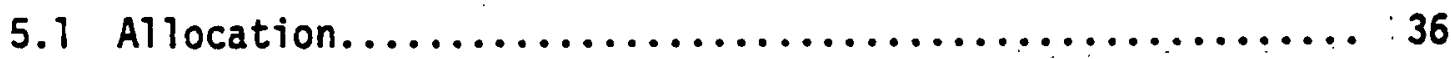

5.2 Redemption Accounts......................... 37

6. Miscellaneous Issues............................. 39

6.1 The Trigger for Rationing....................... 39

6.2 Rationing Implementation..................... 40

6.3 The End of Rationing $. . \ldots \ldots \ldots \ldots \ldots \ldots \ldots \ldots \ldots, 41$

6.4 New Vehicles............................... 41

6.5 Junked Vehicles.............................. 42

6.6 Diesel Rationing.......................... 42

6.7 Unleaded Gasoline............................. 43

6.8 Synthetic Gasoline........................... 44

6.9 Ration Rights for Foreign Visitors.............. 44

APPENDIX

A. Public Comment Classification Form 


\section{A. BACKGROUND}

\section{Introduction}

On June 28, 1978, the Department of Energy (DOE) published its proposed Contingency Gasoline Rationing Plan in the Federal Register, and requested public comments on the plan. In addition, DOE held hearings in twelve cities on the proposed plan, and distributed brief descriptions of the plan to a variety of public interest groups and industry associations.

This report presents a summary of the responses received by DOE.

\section{Purpose of the Plan}

The Energy Policy and Conservation Act (P.L. 94-163) (EPCA) requires the President to develop a contingency plan for the end-use rationing of gasoline in motor vehicles. The plan is to be submitted to Congress for approval. Once approved, it will remain in a standby status, and will not be implemented unless the President finds that a severe energy crisis warrants putting the plan into effect. He would then recommend implementation of the plan to Congress, and if either House does not disapprove within a 15-day. period following transmittal of his recommendation to Congress, the plan would be implemented.

The Department of Energy (DOE) has developed a proposed contingency gasoline rationing plan in accordance with EPCA. The plan attempts to strike a reasonable balance between equitably meeting the diverse needs of millions of gasoline users and limiting the administrative complexity of the plan.

Any gasoline rationing plan will necessarily be costly and administratively complex, cause hardships to many users, and inconvenience large numbers 
of gasoline consumers. Nonetheless, in a period of serious shortage, gasoline rationing in conjunction with price controls would assure all motorists access to some gasoline at a reasonable price. It would also reduce or el iminate long waiting lines at gasoline stations, stabilize the market for gasoline, and mitigate the economic dislocations caused by a severe energy supply interruption.

\section{Surmary of Plan Operation}

Under the plan as proposed in the Federal Register, DOE would allocate "ration rights" (rights to purchase gasoline) to owners of registered vehicles. All vehicles in a given class (e.g., motorcycles; passenger cars) would receive the same entitlement. Essential services would receive supplemental allotments of ration rights as "priority firms."

Once every three months, ration "checks" would be mailed out to all vehicle registrants, allotting them a certain amount of ration rights. These checks would then be "cashed" at Coupon Issuance Points (CIPs), where the bearer would receive ration coupons to be used at gasoline stations. Large users of gasoline could deposit their allotment checks in "ration rights accounts" (1ike checking accounts) at ration banks.

In order to replenish their gasoline supplies, retailers would have to present their suppliers with cancelled coupons or checks written against "redemption accounts" in which cancelled coupon and checks had been deposited.

Coupons or checks would be freely exchangeable in a "white market."

A certain percentage of the gasoline supply would be set aside in reserve for use in national emergencies. Another percentage would be given to the states to use in hardship cases. This State Ration Reserve would be administered by local boards. 
DOE will determine changes to the proposed rationing plan based on its analysis of the public comments. These changes will be incorporated into a final plan which will be published in the Federal Register in the near future.

\section{The Public Comment Process}

In the Preamble which accompanied the Federal Register notice of the proposed plan, DOE solicited written comments on the plan in general and on certain specific aspects of the proposed regulations. In addition, formal hearings were held in the following cities:
- Anchorage, AL
- Kansas City, MO
- Atlanta, GA
- Los Angeles, CA
- Dallas; TX
- Newark, Nu
- Denver, CO
- Portland, OR
- Detroit, MI
- Spokane, WA
- Hartford, CT
- Washington, D.C.

Part of each hearing was set aside so that interested citizens or groups could comment without having been previously scheduled. In this way, DOE hoped to conduct the hearings in the atmosphere of a town meeting, where all concerned parties would be able to comment on the proposed plan.

In addition to its request for comments in the Federal Register, DOE al so solicited comments on the proposed plan directly from private citizens, public interest groups, business and industry, state and local governments, and other concerned groups. In order to give the plan the widest possible airing, DOE sent out several thousand pamphlets describing the proposed plan to interested groups and individuals, distributed press releases, granted intervtews to newspapers, and held press conferences.

A total of 1,126 responses were received before the comment period closed on October 3, 1978. Exhibit 1 shows a breakdown on the numbers received by respondent type. 
EXHIBIT 1

Breakdown of Responses to Proposed Gasoline Rationing Plan

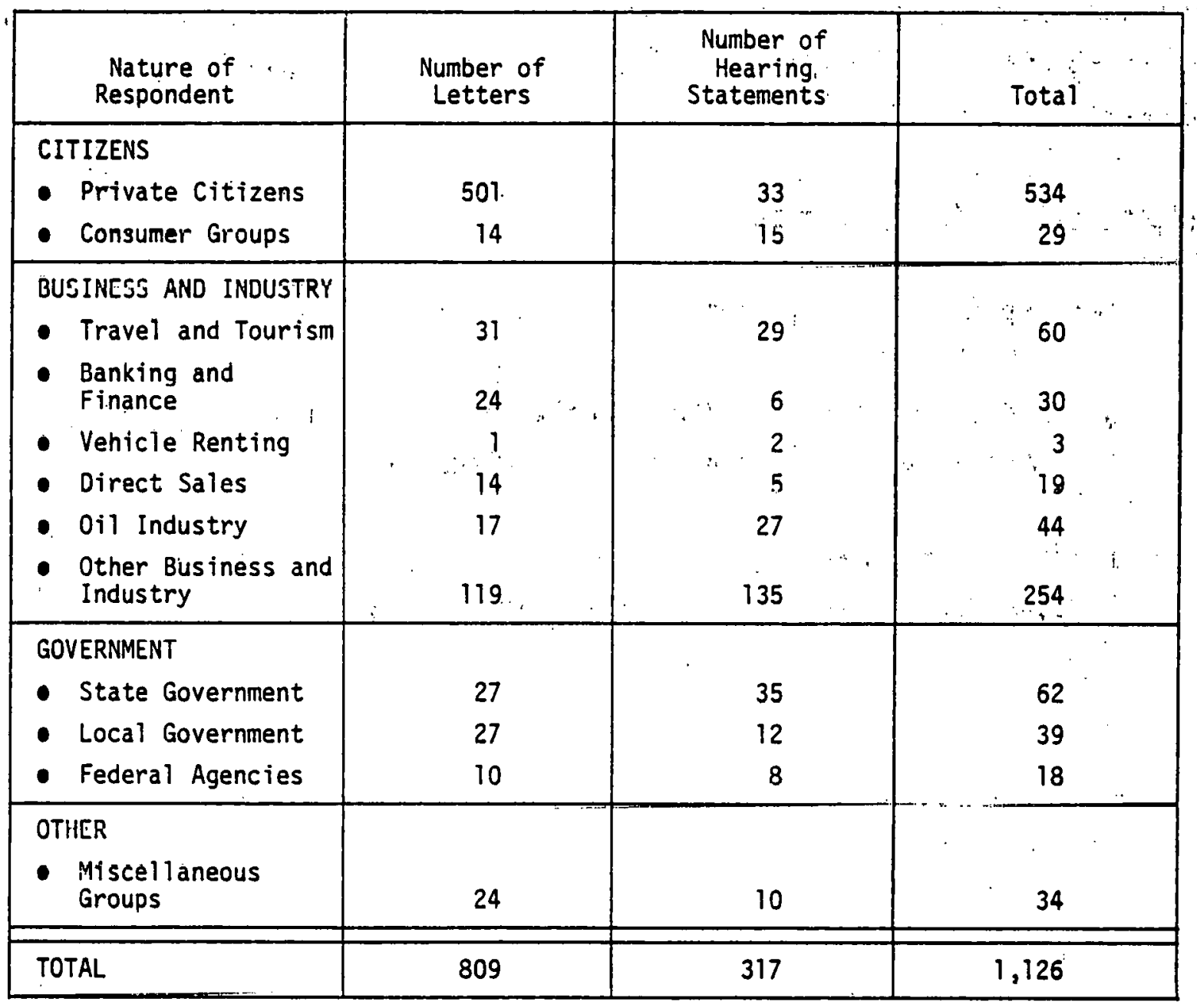


Besides the public comment process, DOE has sought other input on the proposed plan. Prior to the public comment period, the proposed plan was submitted to other Federal agencies for review and comment. Some of these agencies also submitted additional comments through the public comment process:

\section{Organization of this Report}

The remainder of this report is organized as follows:

- Part B describes how the comments were classified, and gives a statistical breakdown of the major responses; and

- Part $C$ is a discussion and analysis of the issues raised by commenting agencies, firms, associations, and individuals. 


\section{B. CLASSIFICATION METHODOLOGY AND STATISTICAL SUMMARY}

Public comments were not received in any standardized format or length. In order to prepare statistical summaries of the comments, a system for abstracting the contents of letters and hearing statements was developed. A Public Comment Classification Form was completed for each comment. (A copy.of the form is attached to this report as Appendix $A$. The first page was used as a summary sheet, with the next three pages spelling out the classification methúdúlugy.)

Many respondents used the comment process as a forum for their complaints about government bureaucracy, school busing, and other issues which are not. relevant to gasoline rationing. These corments were excluded from DOE's analysis.

DOE has assumed that gasoline price controls would be used in conjunction with rationing. Some public coments discussed gasoline prices and price controls. However, those portions of comments which did not explicitly deal with rationing have been excluded from this presentation.

After all comments were classified, the responses were grouped by respondent type and statistical summaries prepared for each group. An overall. summary of the responses: to the most important issues is included as Exhibit 2.

The reader should be wary of drawing any conclusions solely from the statistics given. Some industries (e.g., gasoline retailers) chose to be represented by an industry association in the comment process, whereas other groups (e.g., recreational vehicle clubs and associations) mobilized their members to testify at all hearings and send in as many letters as possible. Although there is some value in looking at the distribution of responses, it is important to understand that the number of responses received does not necessarily indicate either the importance of the issue or the overall public opinion on the issue. 
EXHIBIT 2

Statistical Breakdown of Responses

to Important Issues by Respondent Group

\begin{tabular}{|c|c|c|c|c|c|c|c|c|c|c|c|c|c|}
\hline & \multicolumn{2}{|c|}{ Crtizens } & \multicolumn{6}{|c|}{ Business and Industry } & \multicolumn{3}{|c|}{ Government } & \multirow{2}{*}{ 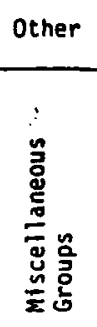 } & \multirow{2}{*}{$\mid \begin{array}{l}\mid \\
\vec{E} \\
\end{array}$} \\
\hline , & 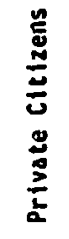 & 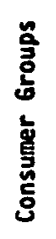 & 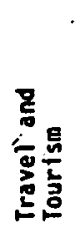 & 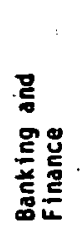 & 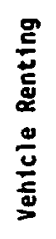 & 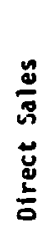 & 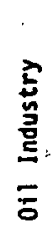 & 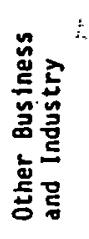 & 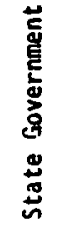 & 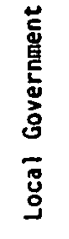 & 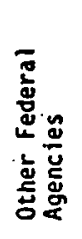 & & \\
\hline Number of Replifes in Group & 534 & 29 & 60 & 30 & 3 & 19 & 44 & 254 & 62 & 39 & 18 & 34 & 1,126 \\
\hline \multicolumn{14}{|l|}{ ISSUES } \\
\hline $\begin{array}{l}\text { Overall reaction to program } \\
\text { - Positive } \\
\text { - Negative }\end{array}$ & $\begin{array}{r}100 \\
12\end{array}$ & $\begin{array}{l}6 \\
6\end{array}$ & $\begin{array}{l}4 \\
6\end{array}$ & $\begin{array}{l}1 \\
6\end{array}$ & $\begin{array}{r}1 \\
--\end{array}$ & $\begin{array}{l}3 \\
2\end{array}$ & $\begin{array}{l}6 \\
7\end{array}$ & $\begin{array}{l}25 \\
21\end{array}$ & $\begin{array}{r}14 \\
4\end{array}$ & $\begin{array}{l}6 \\
8\end{array}$ & $\begin{array}{c}2 \\
--\end{array}$ & $\begin{array}{l}2 \\
6\end{array}$ & $\begin{array}{r}170 \\
78\end{array}$ \\
\hline $\begin{array}{l}\text { Individuals should receive } \\
\text { allotments based on: } \\
\text { - Orivers' licenses } \\
\text { - Registrations } \\
\text { - Other }\end{array}$ & $\begin{array}{l}38 \\
20 \\
16\end{array}$ & $\begin{array}{l}3 \\
3 \\
1\end{array}$ & $\begin{array}{l}8 \\
1 \\
-- \\
\end{array}$ & $\begin{array}{c}-- \\
1 \\
--\end{array}$ & $\begin{array}{c}-- \\
2 \\
--\end{array}$ & $\begin{array}{l}1 \\
-- \\
--\end{array}$ & $\begin{array}{l}4 \\
4 \\
3 \\
\end{array}$ & $\begin{array}{l}9 \\
8 \\
1 \\
\end{array}$ & $\begin{array}{r}11 \\
15 \\
2 \\
\end{array}$ & $\begin{array}{l}4 \\
-- \\
\therefore-\end{array}$ & $\begin{array}{l}1 \\
1 \\
1\end{array}$ & $\begin{array}{r}1 \\
4 \\
-- \\
\end{array}$ & $\begin{array}{l}80 \\
59 \\
24\end{array}$ \\
\hline $\begin{array}{l}\text { Recreational vehicles } \\
\text { should recetve on allotment } \\
\text { index }\end{array}$ & 64 & 2 & 21 & -- & -- & 1 & 1 & 15 & 2 & -- & -- & 1 & 107 \\
\hline $\begin{array}{l}\text { Firms should recetve allot- } \\
\text { inents based on: } \\
\text { - Base period use } \\
\text { - Ragistrations } \\
\text { - Othar }\end{array}$ & $\begin{array}{l}2 \\
1 \\
1\end{array}$ & $\begin{array}{l}1 \\
\ddot{-} \\
\cdots\end{array}$ & $\begin{array}{l}3 \\
-- \\
--\end{array}$ & $\begin{array}{l}1 \\
-- \\
\cdots\end{array}$ & $\begin{array}{l}2 \\
-- \\
--\end{array}$ & $\begin{array}{l}4 \\
-- \\
--\end{array}$ & $\begin{array}{r}10 \\
2 \\
3\end{array}$ & $\begin{array}{r}25 \\
1 \\
7\end{array}$ & $\begin{array}{l}8 \\
1 \\
--\end{array}$ & $\begin{array}{l}-- \\
-- \\
--\end{array}$ & $\begin{array}{l}1 \\
-- \\
--\end{array}$ & $\begin{array}{l}1 \\
-- \\
--\end{array}$ & $\begin{array}{r}58 \\
5 \\
11\end{array}$ \\
\hline $\begin{array}{l}\text { The following firms should } \\
\text { be added to the priority } \\
\text { clossiffication } \\
\text { - Taxicabs } \\
\text { - Highway ma intenance } \\
\text { vehicles } \\
\text { - Energy producers } \\
\text { - Transportation for the } \\
\text { aged } \\
\text { - Utility maintenance } \\
\text { - Emergency road services } \\
\text { - Other. }\end{array}$ & $\begin{array}{c}1 \\
1 \\
1 \\
1 \\
1 \\
11\end{array}$ & $\begin{array}{l}-- \\
-- \\
-- \\
-- \\
- \\
1 \\
1\end{array}$ & $\begin{array}{c}4 \\
-- \\
-- \\
-. \\
-- \\
8 \\
--\end{array}$ & $\begin{array}{c}-\cdot \\
-- \\
-- \\
-- \\
-- \\
- \\
-\end{array}$ & $\begin{array}{l}\cdots \\
- \\
-- \\
-- \\
-- \\
--\end{array}$ & $\begin{array}{l}-- \\
-- \\
-- \\
-- \\
-- \\
-- \\
--\end{array}$ & $\begin{array}{c}-- \\
-- \\
7 \\
-- \\
1 \\
-- \\
\end{array}$ & $\begin{array}{c}32 \\
-- \\
8 \\
-- \\
22 \\
1 \\
6\end{array}$ & $\begin{array}{c}1 \\
-- \\
-- \\
-- \\
1 \\
- \\
6\end{array}$ & $\begin{array}{c}-- \\
-- \\
-- \\
-. \\
4 \\
1 \\
5\end{array}$ & $\begin{array}{l}-- \\
-- \\
-- \\
-- \\
-- \\
1 \\
2\end{array}$ & $\begin{array}{c}5 \\
-- \\
1 \\
2 \\
1 \\
-- \\
--\end{array}$ & $\begin{array}{r}44 \\
1 \\
17 \\
3 \\
30 \\
13 \\
35\end{array}$ \\
\hline
\end{tabular}


EXHIBIT 2 (CONTINUED)

Statistical Breakdown of Responses

to Important Issues by Respondent Group

\begin{tabular}{|c|c|c|c|c|c|c|c|c|c|c|c|c|c|}
\hline \multirow[b]{2}{*}{.} & \multicolumn{2}{|c|}{ Citizens } & \multicolumn{6}{|c|}{ Business and Industry } & \multicolumn{3}{|c|}{ Government } & \multirow{2}{*}{ 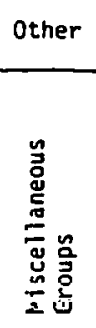 } & \multirow{2}{*}{$\mid$} \\
\hline & 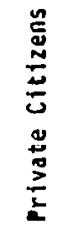 & 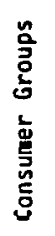 & 后 & 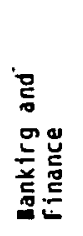 & 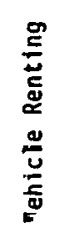 & 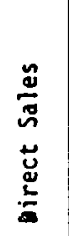 & 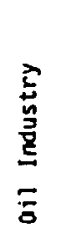 & 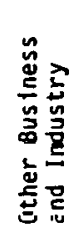 & 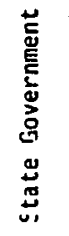 & 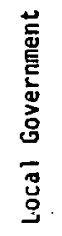 & 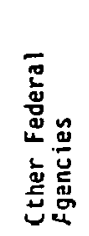 & & \\
\hline Number of Replies in Group. & 534 & 29 & 60 & 30 & 3 & 19 & 41 & .254 & 62 & 39 & 18 & 34 & 1,126 \\
\hline $\begin{array}{l}\text { The criteria for designated } \\
\text { ftrms should be in the } \\
\text { regulations } \\
\text { - Yes } \\
\text { - No }\end{array}$ & -- & $\begin{array}{c}1 \\
--\end{array}$ & $\begin{array}{l}-- \\
--\end{array}$ & $\begin{array}{l}-- \\
--\end{array}$ & $\begin{array}{c}1 \\
--\end{array}$ & $\begin{array}{r}2 \\
--\end{array}$ & $\begin{array}{r}5 \\
--\end{array}$ & $\begin{array}{r}11 \\
2\end{array}$ & $\begin{array}{r}3 \\
--\end{array}$ & $\begin{array}{l}2 \\
--\end{array}$ & $\begin{array}{c}1 \\
. .\end{array}$ & $\begin{array}{c}1 \\
-.-\end{array}$ & $\begin{array}{r}27 \\
2\end{array}$ \\
\hline $\begin{array}{l}\text { Allocation should be: } \\
\text { - Retained as modified } \\
\text { - Modified further } \\
\text { - Oiscontinued }\end{array}$ & $\begin{array}{c}2 \\
5 \\
--\end{array}$ & $\begin{array}{l}-- \\
-- \\
--\end{array}$ & $\begin{array}{l}-- \\
-- \\
--\end{array}$ & $\begin{array}{l}-- \\
-- \\
--\end{array}$ & $\begin{array}{l}-- \\
-- \\
--\end{array}$ & $\begin{array}{l}-- \\
-- \\
--\end{array}$ & $\begin{array}{l}6 \\
5 \\
4\end{array}$ & $\begin{array}{c}1 \\
2 \\
--\end{array}$ & $\begin{array}{r}2 \\
3 \\
--\end{array}$ & $\begin{array}{l}-- \\
-- \\
--\end{array}$ & $\begin{array}{c}-- \\
1 \\
--\end{array}$ & $\begin{array}{l}- \\
-- \\
--\end{array}$ & $\begin{array}{r}11 \\
16 \\
4\end{array}$ \\
\hline $\begin{array}{l}\text { A state adjustment factor } \\
\text { would: } \\
\text { - Minimize hardship. } \\
\text { - Be unfair } \\
\text { - Be unnecessary }\end{array}$ & $\begin{array}{c}1 \\
- \\
-- \\
\end{array}$ & $\begin{array}{r}3 \\
-- \\
-- \\
\end{array}$ & $\begin{array}{c}4 \\
-- \\
-- \\
\end{array}$ & $\begin{array}{l}\ddot{-} \\
- \\
--\end{array}$ & $\begin{array}{l}= \\
-- \\
--\end{array}$ & $\begin{array}{l}-- \\
- \\
--\end{array}$ & $\begin{array}{c}7 \\
-- \\
1\end{array}$ & $\begin{array}{r}5 \\
1 \\
-- \\
\end{array}$ & $\begin{array}{r}15 \\
3 \\
3\end{array}$ & $\begin{array}{c}5 \\
-- \\
--\end{array}$ & $\begin{array}{c}1 \\
-- \\
--\end{array}$ & $\begin{array}{l}1 \\
1 \\
1\end{array}$ & $\begin{array}{r}12 \\
5 \\
5 \\
\end{array}$ \\
\hline $\begin{array}{l}\text { Hardship guidel ines for the } \\
\text { slale Ratlun Reserve 'should } \\
\text { ha- } \\
\text { - Listed in the regulations } \\
\text { - Suggested in the regula- } \\
\text { tions } \\
\text { - Left entirely to the } \\
\text { states' discretion }\end{array}$ & -- & $\begin{array}{l}2 \\
-- \\
--\end{array}$ & $\begin{array}{l}-- \\
--\end{array}$ & $\begin{array}{l}-- \\
-- \\
--\end{array}$ & $\begin{array}{l}-\cdot \\
--\end{array}$ & $\begin{array}{l}-- \\
--\end{array}$ & $\begin{array}{c}3 \\
1 \\
--\end{array}$ & $\begin{array}{l}1 \\
-- \\
-\cdots\end{array}$ & $\begin{array}{l}1 \\
1 \\
7\end{array}$ & $\begin{array}{l}3 \\
1 \\
1\end{array}$ & -- & $\begin{array}{l}- \\
-- \\
--\end{array}$ & $\begin{array}{l}10 \\
3 \\
8\end{array}$ \\
\hline $\begin{array}{l}\text { The witite withet } \\
\text { - Is a good idea } \\
\text { - Would not function smoothly } \\
\text { - Would invite fraud and } \\
\text { thofe }\end{array}$ & $\begin{array}{l}12 \\
15 \\
13\end{array}$ & $\begin{array}{l}i \\
-- \\
1\end{array}$ & $\begin{array}{l}4 \\
1 \\
3\end{array}$ & $\begin{array}{l}-- \\
--\end{array}$ & $\begin{array}{c}2 \\
-- \\
--\end{array}$ & $\begin{array}{c}-- \\
2 \\
--\end{array}$ & $\begin{array}{l}2 \\
6 \\
2\end{array}$ & $\begin{array}{r}9 \\
18 \\
6\end{array}$ & $\begin{array}{l}8 \\
5 \\
2\end{array}$ & $\begin{array}{c}1 \\
-- \\
1\end{array}$ & $\begin{array}{r}-- \\
2 \\
--\end{array}$ & $\begin{array}{c}2 \\
-- \\
2\end{array}$ & $\begin{array}{l}41 \\
49 \\
30\end{array}$ \\
\hline
\end{tabular}


EXHIBIT 2 (CONTINUED)

Statistical Breakdown of Responses

to Important Issues by Respondent Group

\begin{tabular}{|c|c|c|c|c|c|c|c|c|c|c|c|c|c|}
\hline \multirow[t]{2}{*}{ - : } & \multicolumn{2}{|c|}{ Citizens } & \multicolumn{6}{|c|}{ Business and Industry } & \multicolumn{3}{|c|}{ Government } & \multirow{2}{*}{ 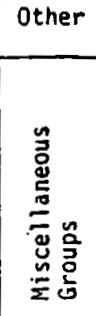 } & \multirow[b]{2}{*}{ 壱 } \\
\hline & 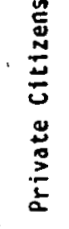 & 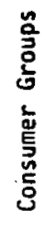 & 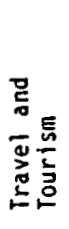 & 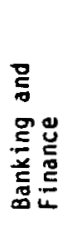 & 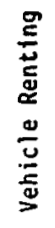 & $\begin{array}{l}\stackrel{\mathscr{U}}{\tilde{n}} \\
\stackrel{\tilde{u}}{0} \\
\stackrel{\mathscr{U}}{0}\end{array}$ & 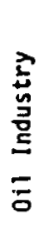 & 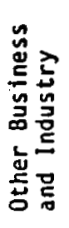 & 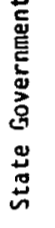 & 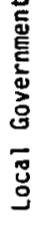 & 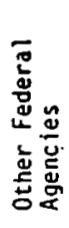 & & \\
\hline Humber of Replies in Group & 534 & 29 & 60 & 30 & 3 & 19 & 44 & 254 & 62 & 39 & 18 & 34 & 1,126 \\
\hline $\begin{array}{l}\text { The white market } \\
\text { - Favors the rich } \\
\text { - Is fair to everyone. } \\
\text { - Favors vehicle owners who } \\
\text { don't need all their } \\
\text { allotments }\end{array}$ & $\begin{array}{l}8 \\
1\end{array}$ & $\begin{array}{r}2 \\
--\end{array}$ & $\begin{array}{r}2 \\
--\end{array}$ & $\begin{array}{l}-- \\
--\end{array}$ & -- & $\begin{array}{l}-- \\
--\end{array}$ & $\begin{array}{c}1 \\
--\end{array}$ & $\begin{array}{l}4 \\
1\end{array}$ & $\begin{array}{c}1 \\
--\end{array}$ & -- & -- & $\begin{array}{l}-- \\
--\end{array}$ & $\begin{array}{r}18 \\
2\end{array}$ \\
\hline $\begin{array}{l}\text { Miscellaneous conments on } \\
\text { - Ration banking (including } \\
\text { coupon redemption) }\end{array}$ & 9 & 3 & $\because$ & 7 & -- & -- & 1 & 4 & 8 & 3 & -- & 1 & 36 \\
\hline - Rationing of diesel fuel & 3 & - & $\cdots$ & -- & $-\cdots$ & -- & .1 & 8 & 3 & -- & - & 1 & 16 \\
\hline - Length of ration periods & 2 & -- & -- & -- & -- & -- & -- & -- & 1 & -- & $-\cdot$ & -- & 3 \\
\hline $\begin{array}{l}\text { - Al lotments to faderal } \\
\text { government }\end{array}$ & -- & 1 & - & -- & -- & - & -- & -- & -- & -- & -- & -- & 1 \\
\hline $\begin{array}{l}\text { - Economic, regulatory and } \\
\text { environmental analysis }\end{array}$ & 3 & -- & 1 & -- & 2 & -- & 1 & 8 & 4 & 1 & -- & 1 & 21 \\
\hline
\end{tabular}




\section{PRESENTATION OF ISSUES RAISED BY RESPONDENTS}

\section{Introduction}

The following sections address the wide range of issues that were of concern to respondents. Each section presents a synops is of the comments on an issue, and also gives one or more direct quotes that discuss the issue in a particularly succinct way. 


\section{Allotment Issues}

2.1 The Basis for Firms Allotments: Vehicle Registrations vs. Base Period Consumption

Comments on this issue heavily favored using base period consumption as the basis for ration allotments for firms. Many respondents described their dependence on gasoline as essential for their non-vehicle gasoline-powered equipment and delivery of goods and services, and stated that a uniform vehicle allotment would not meet their needs. Many firms stated that they were already using their vehicles as efficiently as possible. Some firms also pointed out the need for seasonal adjustments and allowances for growth in computing the base period allotments.

Several respondents requested that, if base period calculations were used, DOE utilize existing recordkeeping mechanisms so as not to impose more bureaucratic requirements on firms. The American Trucking Association pointed out a discrepancy between base period calculations under the allocation regulations and under the rationing plan for designated firms.

Many firms pointed out that their employees often use their personal automobiles to conduct company business, and requested that this be taken into account in calculating base period usage.

"A gasoline-powered four-axle tractor semitrailer averages 9,607 miles per year when used by the forestry industry, but 43,900 miles per year when used by the wholesale and retail industry. Obviously, fuel usage is not a function of axles and gross vehicle weight."

- American Trucking Association

"The salesman may drive 40,000 miles each year in covering his three and a half state territory. If he were to average $15 \mathrm{mpg}$, he would require 2,666 gallons of gasoline exclusively for business use. Yet, under the Department of Energy plan, he would receive no more gasoline than a teenager who...could use his allotment to go to and from schoor...

-- Bureau of Salesmen's National Associations 


\subsection{Priority and Designated Firms, and Special Circumstances}

The proposed rationing plan allows certain essential services to receive a percentage of their base period gasoline use as priority firms.

Although not all requested designation as priority users, many comments were received from firms and industry associations urging special consideration for their gasoline needs. The following list identifies these groups and provides their justification for special consideration:

- Agriculture -- because food production is essential to public welfare, and because food products are perishable and require immediate transportation.

- Electric power utilities -- in order to maintain service.

- Telephone companies -- in order to maintain service. Telephone communications would probably increase during rationing as travel becomes restricted.

- $0 i 1$ and gas industries -- because rationing would not function smoothly unless fuel supply deliveries to retailers can be maintained.

- Mining companies -- because American industry depends on adequate raw material supplies.

- Postal vehicles, including privately-owned vehicles used for rural deliveries -- because Congress has called for the maintenance of essential public services (including mail delivery) during energy emergencies. The use of postal services would probably increase during rationing as travel becomes restricted. 
- Package delivery and courier companies -- because use of their services would probably increase during rationing as travel becomes restricted.

- Armored car companies -- because their services will be required to transport ration coupons in addition to their normal currency transportation duties.

- Freight hauling -- in order to maintain American business at full operations. This is even more essential during rationing because an energy shortage would have a depressing effect on the economy.

- Van pools -- because they provide fuel efficient means of passenger transportation.

- Taxis -- because they provide special-transportation services to the handicapped and elderly, and because in many areas they are the only form of public transportation.

- Mass public transit companies -- although they will be classified as priority firms, they may require more than $100 \%$ of their base period usage because demand for their services will probably increase during rationing.

- Airlines -- in order to have sufficient fuel to operate ground service vehicles. Use of air travel will probably increase during rationing.

- Salespersons -- because their personal sales visits are essential to business relationships. 
- Automobile manufacturers and-dealers -- because they would receive no allotments for "dealer-plate" registrations, al though they... would need gasoline for demonstrating cars, and giving new car: owners enough gasoline to drive to the nearest gasoline station.

- Emergency road services -- because they provide essential services for American motorists.

- Newspapers and broadcasting -- because reporters must travel to cover the news. The media will also play a key role in explaining the rationing program to the publtc.

- Medical and pharmaceutical services -- in order to allow doctors" visits to patients' homes, and pharmacists' drug deliveries.

- Attorneys -- because they provide important professional services.

- Volunteers and social service agencies -- because they provide essential transportation and other services for the disadvantaged, and because they do not have the funds to purchase coupuns on the white market.

- Clergymen -- in order to visit the sick and elderly.

Special consideration was urged for the elderly, the rural poor, and for people who need to drive their cars to remote work sites as part of their jobs (e.g., construction workers).

Noting that not all services provided by priority firms are necessarily essential, a few respondents suggested that supplemental ration rights should be given on the basis of priority uses, rather than a blanket issuance of ration rights to priority firms. 
Oniy a iew comments meritioned the white market as a possible source of extra ration rights, and those comments tended to claim that whita market ration rights would be too costly or too difficult to find to meet the firms' needs. In order to prevent white market abuses by priority firms, one organization proposed a special type of non-sellable coupon to be given to priority users.

"Transportation for the elderly and handicapped... is one of the most essential services performed by a taricab. Mass transit and buses io not have the cability to provide the necessary door-to-ioor services for these segments of the population.

"The important question is, does the tricab periom a vital and essential transportation function and, therefore, is entitled to be classified under Section $F$, Eriomity Class Eizms?:?

\section{- Intermationai Tazicab Association}

"Section 20.3 of the Energy Policy and Conservation Act comies forward the allocation priorities of ... the Emergency Petrolewin Allocation 'Act of 1973. One of these priorities is: maintenonce of all oublic services incluaing tronsportation facilities and services which serve the puilic at large.

Mith respect to this priority, the Bouse Interstate and Forsign Commerce Commitiee reporit stated: 'the mainienonce of all public services callec for in suosection B! would embrace puilic transportation, mail delivery, and all levels of goverment. "

\section{-- U.S. Rostal Service}

"Zave all firms that desire 'priority firm' and 'priority status' designations suomit and have on filz with the Deparment of Energy a specific detailed listing of their emergency sernices...that would cualify for 100\% filel allotments." 
One respondent felt that priority designation could be more effectively done at the local level:

- "If priorities are set by federal agencies on a nationaide basis, as implied by the draft Plan, they are far more likely to be at variance with local needs..."

-- Southern Califormia Associaiton of Governments

The vast majority of respondents who addressed the issue of "offhighway" designated firms felt that the designation criteria should be laid out in the proposed regulations rather than waiting until rationing were implemented.

"Businesses will want to know sufficiently in advance those standards, criteria and formulae that must be met in order to qualify for selection as a 'designated firm' and for initial and supplemental allotments. Such knowledge would permit businesses to begin, in advance of implementation of gasoline rationing, to establish the systems of records and to collect the data that will likkerly be a prerequisite to their meeting such criteria."

'-- American Automotive Leasing Association

rObviously, DOE/ERA will not have sufficient time to adequately consider each application for selection as a 'designated firm' or class of firms on an individual basis. The oroblem will become crucial if the white market does not begin to function immediately."

-- American Trucking Association 


\subsection{Farmers}

Most comments received from the U.S. Department of Agriculture and farm organizations, such as the National Council of Farmer Cooperatives, stated that farmers should receive $100 \%$ of their gasoline needs so that there would be no disruption of food production. These comments did not usually address the white market as a source of ration rights, and the ones that did pointed out that it would be difficult for farmers to pass through white market costs since farmers do not usuality set prices.

Respondents urged that special consideration be given not only to the farmers themselves, but to the entire food industry. The National Council of Farmer Cooperatives proposed a definition of agricultural production to be added to the section on priority firms: "Agricultural production means essential activities, including packaging and distribution to point of final sale, involved in agricultural production, natural fiber production, food processing, natural fiber processing, food quality maintenance, irrigation pumping, crop drying, and the production and distribution of fertilizer, agricultural chemicals, animal feed and food."

"Agricultural production is a biological process timed by the sun, the seasons, and the rains. Unlike manufacturing processes, it is not anenable to significant stockpiliny on short rotice or production delayc for fuel allocation or rationing. Any dismption of the process can couse farm output to be lost, not just for the period of energy withdrawal but for an entire season."

-- National Council of Farmer Cooperatives

"If famers utilize the 'White Market' to purcinase coupons for suoplemental gasoline, it will increase their production costa and reduce net incomes. Unlike most industrial firms, they could not recover their increased costs by passing them through to the consumer because farmers generally do not set prices. Host farm products are sold in a froe market. Even with a Goverment supported market, farmers cannot recover increased costs unless the market price of food is increased, and this would contribute to inflation." 


\subsection{Leased and Rental Vehicles}

The American Automotive Leasing Association (AALA) maintained that motor vehicle leasing, particularly the leasing of fleets of vehicles to businesses, presents special circumstances which warrant the issuance of ration rights directly to the lessees as "eligible individuals." (Under the present plan, ration rights would be given to the leasing companies and then transferred to the lessee.) The leasing companies would provide lists of vehicles and lessees to ERA.

A major vehicle renting company proposed the following definition for leased vehicles: "a motor vehicle under a bailment contract of no less than one year."

"ACRA fully concurs in the recomendation that ration allotments issued for leased vehicles operated by lessees must be transferred to the lessees." " 
2.5 The Basis for Private Individuals' Allotments: Yehicle Registrations vs. Orivers' Licenses

Comments on this issue generaliy favored drivers' licenses over vehicle registrations as the basis for individuals' allotments. Individuals preferred licenses to registrations by a substantial margin, while comments by government and business were about evenly divided betiveen licenses and vehicle registrations for individuals' allotments. Citing notions of fairness and equity, many respondents felt that the number of cars owned did not reflect the amount of essential driving the members of a family performed. Thus, onecar multi-driver families were considered to be especially hurt by the vehiclebased allotment system. Some letters proposed limiting the total number of allotments per family regardiess of the number of vehicles owned.

"TEA concurs with the Deporment of Energy that the most equitcible and ejficient system on which to tase ration allotments curring a sudien supply shiontage is vehicle registration:"

\section{-o Tennessee Energy Authority}

"The decision to distribute coupons on the basis of automobile registration rather then drivers licenses favors fomilies ouning more than onte car. Low income people do not have the lusury of several outomobiles. Frequently, on entire forily depencis on a single vehicite to cormy all of its memiers to and from work and scriooi."

-- Independent Gasoline Marketers Association

"I hope the Carter acministration does not have to develop a food rationing plan. Apocarenti: the Aiministration would base a jemily's food allotment on the momber of refrigerators they own and not on the nomier of childisen to be fed." 
Many additional comments, especially from private citizens, cited problems with the vehicle based allotment mechanism (e.g., the problem of junked vehicles receiving allotments), but these comments generalily did not endorse drivers' licenses specifically as a preferred alternative.

Another problem that was pointed out by several states and the Motor Vehicle Manufacturers Association involving vehicle based allotments was the presence of many errors in State Department of Motor Vehicle (DMV) files.

"A'review, prompted by the statistics reflected in the proposed gasoline rationing plan, has indicated a possible error factor of up to $25 \%$ in own velivile registration statistics."

-- Pernsylvania Energy Councir 


\subsection{Recreational Vehicles (RVS)}

Many comments were received on the proposed plan's exclusion of allotments for recreational vehicles. While a few respondents agreed with the zero allotment for RVs, most were opposed, citing serious problems in defining a recreational vehicle or distinguishing an RV used for pleasure from one used for business or commuting. The question was also raised whether motorcycles and vans are recreational vehicles.

Both travel-related industries and states whose economies are dependent on tourism urged that RVs receive allotments, and some went on to propose special additional allotments for summer vacation travel.

"DOE's position that recreational driving, being discretionary, is therefore also unnecessary, represents what social scientists agree is an incorrect... view of the facts of life."

-- Recreational Vehicle Industry Association (RVIA)

"Many fomilies use their $R V$ as a means of transportation. People drive pickup trucks and vans to work. Retired individuals live full time in $R V^{\prime} s$, and they serve as their only form of transportation. Travelling oalosmen have found it more convenient and less expensive to live and travel in the same vehicle, and their $R V^{\prime} s$ have become vital parto of their business."

-- The Good Sam Club

"It was not the estimatod 9 to 12 percent decrease in gasoline supplies that brought our industry to its knees [during the 1973-74 embargo]. Rather, it was consumer uncertainty over the availability of gasoline. Uncertainty is by far the worst possible cloud of doom that could hover over our industry... The proposed rationing plan would be devastating for this some reason. It would not be possible for the RV owner or prospective purchasor to know how much gasoline he could get or at what price." , 


\subsection{Allotment Entitlements}

There were a number of specific comments made on the allotment indices and vehicle definitions that were proposed in this plan.

Many motorcycle representatives thought the proposed al lotment index of 0.1 for motorcycies was too 10 w.

we suggest that a distinction be made between motorcycles and other two-ungeled motorizad veiricles... [In addition, we feel that] 0.2 would be a more correct and realistic indew jor motorcycles based on cuailable data."

-- American Motoroyclist Association

Several respondents felt that Gross Venicle Weight (GVW) was a poor basis on which to allot gasoline. A trucking industry representative pointed unt the GVW does not take into account actual distances travelled annually, type and weight of cargo carried, driving conditions (open highway vs. city), or seasonal variations in vehicle use. Several respondents pointer out that nine states and the District of Columbia do not have GVW information in their State DMV files.

\footnotetext{
"iross vehicle weight is totally irrelevant to the factors inat a rationing pian must deal with to obtain the maximum of transportation for a minimon of juel."

- A purkage delivery compary
}

"There is nothing to prevent me, other than cost, from registering $m y$ station wason at $3 \leqslant, 000$ [pounds GVW] ond oblatiring seven times the aliotment. I really an entititied to. 


\section{Coupon Related Issues}

\subsection{Coupon Issuance and Ration Banking}

Comments received from banks and the American Bankers Association (ABA) on the banks serving as coupon issuance points were negative, and stressed that full reimbursement for costs would be necessary if they were to participate.

\footnotetext{
"As presently proposed... that portion of the plan that requires that consumers present and identify themselves to banks to exchange ration checks for ration coupons is unacceptable because of its unnecessary adverse impact on the lives of millions of those consuners."

-- American Bankers Association
}

The ABA submitted detailed corments on many Coupon Issuance Point (CIP): issues, including the following:

- The qualifications for CIPs should be designed to assure maximum participation by major retailers, as well as financial institutions.

- DOE should specify the acceptable uniform identification required by the CIPs and/or develop a standard ID instrument which could be used for ration check cashing purposes. In addition, CIPs should be relieved of any liability they might incur in relying on the DOE-specified identification.

- DOE should develop and publish an acceptable schedule of fees to be paid to CIPs.

- DOE should issue only one ration check per quarter. 
- If the total length of rationing is expected to exceed 12 to 18 months, DOE should cycle the distribution of checks over the total working days in each ration quarter.

- Coupons should be prepackaged for distribution in amounts equal to the gallon entitlements printed on the ration checks.

Post offices, credit unions, savings and loans, and even retail gasoline outlets were proposed in several comment's as coupon issuance points and ration banks, although not by these entities themselves.

The $A B A$ also proposed the direct mailing to eligible recipients of packets of personalized coupons in fixed gallon amounts. These coupons could be used directly at gas stations. The direct mailing would el iminate the cost and difficulty associated with coupon issuance from banks and other institutions.

In the plan narrative, DOE suggested the possible use of computer generated lists of vehicle registrants as a substitute for ration checks. The ABA opposed use of such lists because they would be more costly and time consuming for the banks to utilize.

The ABA cautioned that the Uniform Commercial Code (UCC) used to decide liability for fraudulent checks would not apply to ration checks because they are not monetary instruments.

The Federal Reserve Board (FRB) commented that the volume of paper involved with the use of coupons added to normal currency operations (including transportation and storage) would strain the capacity of existing financial institutions. FRB also requested that coupons be designed so that they can be counted by the currency counting equipment available to banks. With respect 
to printing new coupons, FRB stated that it would require most, if not all, of the annual note printing capacity of the Bureau of Engraving and Printing in 1979 for printing currency.

"The adiitional 20 jillion pieces of paper anralitiy will substanitally increase the mount oj gever now handiled by the inoncial industry, and itit strain the capcaity of fincencial institutions to handie normal payments."

-- Fecierar Reserve Bocara 


\subsection{The White Market}

Many firms stated that al though the concept of a white market was a good idea, in practice the white market would not function smoothly. The respondents felt that vehicle owners would hoard their ration rights, at least initially, driving the price of the few available ration rights too high for businesses to be able to use them.

"Ore courier corporation estimates that it will receive only $1 \dot{3}$ days worth of needed coupons. The remainder necesscary to operate their business must be purchased on the white market. If the white market mechanism is not established within this time frame, this company will be out of business. For most sompanies, higher prices are preferable to the uncertainty sumounding the white market."

\section{-- American Trucking Association}

A common prediction among private citizens was that "the white market would become a black market," al though many of these perceptions appeared to be a result of citizens' reluctance to pay a premium for ration rights in addition to the pump price for gasoline. Some individudis predicted that the market would not function at all as everyone would hold onto all their coupons in anticipation of a worsening of the gasoline supply situation. Most respondents felt tht the white market favored the rich, since only they would have the money to purchase extra ration rights at the high white market prices people foresaw. Some respondents felt that the white market would be inflationary, or would discourage conservation.

A number of comments proposed Federal regulation of the white market, including price regulation.

Independent gasoline distributors expressed fears that the major oil companies would use their advantages in capital and nationwide market position to purchase coupons on the white market, and then make those coupons available for sale at their retail outlets. This would give them an unfair advantage over the independents. 
Some industry groups stated that they might not be able to pass the white market costs through to their customers, either because of fixed price contracts (e.g., construction companies) or because their prices are determined by market forces rather than cost (e.g., farmers).

"If calling the black market the white market makes it acceptable and legal, and if the rationale for this arrangement is the presumed unenforceability of laws to the contrary, then by the same logic we might as well rename all those crimes which are difficult to control and thus eliminate criminal activity in total."

-- Wașhington Trucking Association

"The only difference between rationing under this proposal and simply allowing the market to set a price is that the economic benefits of a shortage will be transferred from refiners and suppliens to individual car owners. The people who will profit the most will be those who own the most cars. This we submit is, bad public policy."

- Independent Gasoline Marketers Association 


\subsection{Coupon Denominations}

Motorcyclists, and owners of vehicles with small gas tanks, requested that coupons be issued in smaller units than 5 gallons. This comment was supported by other groups.

"We recomend that a number of the coupons be in one-gazlon inwernents inther thun being solely confined to 5-gailon coupons as proposed."

-- A major oil company

"It is a fact of iife that we are constantly exposed to armed robbery and pilferage by employees... [In order to prevent this] imiviy of cur memiers have an exact change policy to eliminate the need for a cash drawer during the late night hours or in dongerous inner city locations. This means that customers buy gasoline in round dollar amounts. If a customer must present two forms of money, one in dolzars and one in galzons, exact change lor exact gallons] is impossibie."

-- Independent Gasoline Marketers Assoveration 


\subsection{Expiration of Ration Documents}

Several respondents suggested that ration coupons only be valid for one or two ration periods.

"There is concern over the potential hoarding of coupons by individuals. Since the purpose of rationing is to fairly distribute the gasoline which is available in a specific. time period, it appears to make little sense to allow the coupons to remain valid indefinitely...A system of this nature [i.e., giving coupons an expiration date] would conceivably reduce the potential for persons to hoard the coupons and force individuals to use them or exchange them in the white market."

-- Pennsylvania Energy Council

"Under the proposed plan, rationing checks are to be issued each.90 days and would not have expiration dates. We suggest that all ration rights must be utilized within the 90-day period or be lost. Such a provision will allow the [Energy] department more control in fine tuning the supply/demand equilibrium in a crisis situation."

-- A major oil company 


\section{State Issues}

\subsection{Use of a State Adjustment Factor in Computing Allotments}

A number of comments were received on this issue, especially from state governments. These comments heavily favored a state adjustment factor as a way of reducing hardship and inequity in the plan. Some State Energy offices suggested that the factor be based not only on fuel consumption, but on other factors as well, for example the amount of public transportation available, the concentration of gasoline intensive industries (e.g.. tnurism): within the state, or the number of priority vs. non-priority firms in the state.

"It should be noted also that California drivers are subject to a $10 \%$ fuel penalty because of the stringent emission controls imposed by the State. Any formula adopted... to establish differential allotments conong the several states should compensate for such extermally-imposed restraints on fuel conservation."

-- Southern California Association of Goverrments

"Use of a State Adjustment Factor seems to create as many problems as it eliminates."

-- Califormia Department of Transportation

"We conour with the DOE that this lack of data, together with the uncertainties of changed driving patterns duming a supply-limited situation, suggests that state adjustment factors not be used. The white market will permit the acquisition of needed ration rights and state reserves can be used to handle hardship cases, if necessary.". 
"A token solution...state averages do not realzy resolve the basic problem that some people need more gasoline than others because the state they live in really has at best very little to do with an individual's relative gasoline requirement. Incorporation of a State Adjustment Factor only opens the door to an endless parade of requests for other adjustments of equal merit.".

-- A major transportation company

Some respondents felt that a single adjustment for all state residents was too broad, since it ignored important rural-urban differences within a state.

Some states which had gasoline consumption figures below the national average (e.g., Florida, Connecticut) were opposed to a state adjustment factor. The state of Washington, however, was an exception:

"After reviewing the data supplied by $D O E$ on the per-capita gasoline consumption by State, we found ourselves supporting a variation in its basic allotment by state. Although under such a plon, Washington would 'lose', we feel that in the interest of fairmess, all drivers in all states. should cut back their gasoline consumption to the same level."

-- Washington State Energy Office 


\subsection{State Ration Reservès (SRR)}

Relatively few comments were received on the State Ration Reserve system. Some respondents felt that both an SRR and a state set-aside would" be necessary during rationing. One oil distributor and some states felt that a 3\% SRR seemed sufficient based on experience with the set-aside in the allocation program, although other comments proposed a higher amount. The State of Nevada said that an SRR larger than $7 \%$ would impose too large an administrative burden on the states. Some states suggested leaving the specific size of the Reserves open to individual negotiation with DOE at the time rationing is implemented, based on individual state circumstances.

"We understand the Administration proposes, in order to ease passage through Congress, that the setaside percentage not be specifically and finally defined in the legislation. We have no quarrel with that strategy decision: frankly, the govemors and their energy advisors have not reached a hard concensus on liut percentage, although it appears $3 \%$ to $5 \%$ would be wide $z_{y}$ accepted."

-- National Covemors Association

"Maintenance of oument operation of the state set-aside is necessary in order for the state, to continue to control distribution of gasoline in hardship cases. Implementation of rationing should not interfere with the state's current role in administering the set-aside."

-- Massachusetts Energy Office

Most states favored broad federal guidelines and considerable local flexibility in the management of the State Ration Reserves. Business and private groups favored more specific federal guidelines, however! feeling that allowing states too much discretion left them open to political influence. 
One oil company suggested that use of the SRR should be primarily for individuals and small businesses. For larger organizations (using more than, say, 20,000 gallons per year), the appeal for additional, ration rights should be directed to DOE.

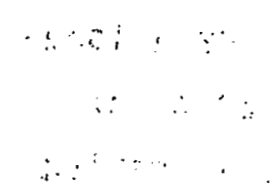

"Guidelines from DOE should include types of situations that it would consider to be a hardship case, with the States hoving discretion to define. additional types of hardship cases on their own. It should be borne in mind that no matter how general the guidelines are, exceptions will always be found, and the stricter the guidelines are, the more exceptions there will be."

-- Washington State Energy Office

"We believe applicants for the State Ration Reserves must show conservation efforts. In addition, we believe recipients of the Reserve should not be allowed to trade their coupons on the white market."

-- American Trucking Association 


\subsection{State Funding}

Many states and the National Governors Association were emphatic that full Federal funding would be required to operate the State Ration Reserves, and to cover the cost of detailed planning for the overall state role in rationing.

"Wo know of no state wher"e sufficlent resources are avaitable to the energy office and/or the governor's office to finance the hige role assigned the states under this plan."

\section{-- National Governors Association}

"Prion to impienertition of any plan, a significant amount of planning and training must occur to assess Department of Motor Vehicle information; alter DMV data collection procedures, if necessary; set up and train staff for local state reserve offices and appeals boards, and inform the public of necessary procedures so that the rationing prograin mus as smoothly as possible...DOE should evaluate the administrative burden placed upon the states at each of these stages and should make corresponding funding allowances."

-- Massachusetts Energy Office 


\subsection{Alaska}

$\therefore \quad$ Practically all the comments from the Anchorage, Alaska public hearing suggested that the state of Alaska be exempted from any gasoline rationing program: The reasons for this exemption were given as follows:

- The entire population of the state is only 400,000 people, so the impact on the total energy situation would be minimal. Many of these people are widely dispersed geographically and would have to travel long distances (using up gasoline) in order to pick up ration coupons.

- Fuel and gasoline is delivered only once or twice a year to many locations, so that the redemption account controls on suppliers would be difficult to enforce..

- The State DMV.'s address files are 20 to $30 \%$ inaccurate.

- Many Alaskan vehicles are off-road (e.g.j bush vehicles, snowmobiles) and are not registered with the State DMV.

- Alaska is in a major energy development mode, and needs plenty of fuel to maintain the development pare.

The State Energy Office assured DOE that, even if Alaska were exempted from a rationing program, it would implement a conservation program to cut down on non-essential uses of gasoline.

"I would dirie muke the bold statement that we would spend more energy trying to get the [rationing] system enacted in Alaska than we would in the fuel savings that would result." 
5. $\quad$ il Industry Related Issues

\title{
5.1 Allocation
}

Most comments by oil products distributors favored the retention of the allocation program during rationing. Some oil companies suggested that allocation controls be used during the 45-day implementation period, then removed.

\begin{abstract}
"The consumsr can be expected to spend his coupons at thoes retailer's who are continuting to maintain competitive levels of price and service. The use of allocation volumes should be eliminated."
\end{abstract}

$$
\text { - A major oiz company }
$$

"Allocation relationships between suppliers and wholesale or bulk purchasers [should] be maintained duming rationing, and a timo period [should] be estabiished for the: lifting of surplus gasoline so that as much normalcy as possible may be maintained in the market place, and so that exooos supplies may be efficiently and speedily rediperted."

\section{-- Tennessee Energy Authority}

Several comments underlined the need for allowances for shrinkage and evaporation.

"Ono of the things wo would like to emphasize is that you should now spell out how you would recognize shwinkage on petroleum.products... We lose one percent in volume for each 16 degrees variation in temperature... Every livensed wholesale aistrioutor has figures which would justify the shrinkage."

-- Society of Independent Gasoline Marketers of America 


\subsection{Redemption Accounts}

Most oil industry representatives supported the idea of an initial redemption account advance; however, there was little agreement as to its proper size. Suggestions included:

- "..10,000 gallons, which would cover the largest single delivery." -- A large oil company

- "..the 10-day consumption advance is a more rational approach." -- Society of Independent Gasoline Marketers of America

- "..one half the allocation amount."

-- National Oil Jobbers Council

- "...the conount of two loads or 17,000 gallons." -- A large oil company

- "... the advance could be uniform for various volume ranges within each level of gasoline supply."

-- A major oil company

Some respondents were concerned about the logistics of turning cancelled coupons or redemption account checks over to suppliers.

"The logistics involved and existing accounting systems make the transfer of ration rights at the time of exchange or sale to other suppliers impractical. Compliance with the plan's accountability requirements and adequate control can be accomplished by periodic reconciliation of all transactions by the wholesaler supplier and the DOE."

-- A major oil company 
"In many cases terminals are key or card lock and the wholesaler lifts gasoline to be billed at a later date... Under these circumstances, it would be impossible to prevent over-lifting... [We urge] DOE to clearly provide that the legal liability for excessive product pickups at such terminals rests upon the wholesaler purchaser and not upon the supplier..."

-- A small oil company

"If the supplier refuses a check and insists upon receiving cancelled coupons, that supplier could significantly disadvantage that marketer...By refusing the cheeks of independents, the supplier could force those marketers to physically produce the cancelled coupon. That is even more onerous than insisting upon cash because it may be a lot harder to borrow coupons than it is to borrow money."

- Nationai Oil Jobbers Council

Several respondents mentioned possible problems with bad checks received from gasoline purchasers. A related problem dealt with the fact that many gasoline stations are now self-service -- vehicle owners could fill their gas tanks without first producing coupons.

"[In cases of bad checks] we would recommend that suppiiers utilize their normal procedures in order to oecure aufficient ration rights from the oustomer to make the check good."

A Zarge oil company

"[In the case where a firm!s check is bad and the supplier must sue to get ration rights:] Eor small suppliers, it may prove difficult to obtain from the 'white market' sufficient ration rights to continue operation while a remedy is being sought. In view of this, we recommend some procedures be established whereby the supplier can borrow ration rights pending the resolution of his action." 


\section{Miscellaneous Issues}

Respondents also addressed a number of other issues. For example, some comments expressed concern that al ternatives to rationing had not been fully considered by DOE. A few respondents commented that the proposed plan was too general. Other important issues are presented below.

\subsection{The Trigger for Rationing}

Some respondents stated that rationing should never be used under any circumstances, while many others said that it should be used only as a last resort. Some comments suggested that the allocation program alone was sufficient to handle a gasoline shortage.

Some private citizens, but almost no firms or organizations, supported rationing as a good way to force conservation of energy resources.

The Motor Vehicle Manufacturers Association (MVMA) urged DOE not to trigger rationing at gasoline shortfall levels below 25\%. Stating that the 1973-74 embargo appears to have caused a gasoline shortfall of $14 \%$, the MVMA expressed the view that a shortfall of the same or even silightly greater magnitude would not warrant a program as expensive and cumbersome as rationing. This view, that the 1973-74 shortage was not serious enough to have warranted rationing, was reiterated in other comments:

"A point should be established which represents a more serious shortfall in supplies than that experienced in 1973-74 during the Arab Oil Boycott... While the oil embargo inconvenienced many car owners by creating unusually long lines at the gas stations, compared with the seirious administrative problems and substantial costs associated with a gas rationing progrom, this inconvenience would be a preferable alternative should similar shortages occur."

- National Automobile Dealers Association (NADA) 
"The second definition of a reason for implementation, 'in order to fulfill obligations of the United States under the International Energy Program,' is totally unacceptable. In essence this provision would transfer control of internal policy to foreign powers, and it allows selective foreign punitive action to the taxpaying public."

-- A major public utility company

\subsection{Rationing Implementation}

Several comments were received on the proposed length of the implementation period for rationing.

"We believe that the current plan could not be made to function satisfactorily in a 45-day period."

-- Federal Reserve Board

"The Committee sees the 45-day poriod noodod to $\mathrm{im}$ plement the Contingeney Plan as the weakest link in the Gasoline Rationing Plan. If a fuel energy occurs the cricial period is now immediate. The citizenry cannot be held in abeyance for the 45-day period."

-- Los Angeles Area Chomber of Commerce

"A preferred system would be to allow the President to request the cuthority to implement the rationing plan. From the time of the formal request, the mechanics of implementation could proceed until the system is ready for. immediate implementation. The system would only become effective after an approval by both Houses of Congress." 


\subsection{The End of Rationing}

Several respondents felt that explicit provisions for ending rationing should be included in the rationing regulations.

"There should be an acecucte notification of the end of rationing to minimize economic dismiotion."

- Washington State Energy Office

"The Proposed Plan fails to address the issue of. orderly termination of the rationing period. The revised Plan should incorporate provisions for a final accounting by retailers, supoiiers, and distrioutors."

-- Massachusetts Energy Ofjice

"First, the 'Conitingency Zlan 'in toto' sinould have a defined life [perhaps five years]. In addition, each implementation period [sic] should include $a$ manimon defined duration with automatic termination at the end of said period."

-- A major public utility company

\subsection{New Vehicles}

Comments from vahicle manufacturers and dealers pointed out the importance of new vehicle owners' receiving their initial supplies of ration rights quickly.

"The long time in issuance of ration rights for a newly-purchased vehicle could be eliminated if stair DMV offices vere anthorized to issue initial ration rights with the temporary registrations for a newiypurcinased vehicle." 


\title{
6.5 Junked Vehicles
}

Many respondents pointed out that basing ration allotments on vehicle ownership could motivate people to purchase junked vehicles or retain old vehicles in order to receive extra ration rights.

\author{
"Almost 10 million motor vehicles are presently \\ scrapped each year. If ration rights are based on \\ vehicle registrations, the oumer of a wresked or \\ obsolete vehicle may decide to postpone the destruction \\ of that vehicie's registration." \\ - Motor Vehicle Manufacturers Association.
}

\begin{abstract}
"An anoillary off-shoot which could conceivably occur at least in the initial stages of the rationing plan if vehicle registrations were the basis for coupon allocations would be to create an artificially higher value for used cars and also potentially decrease the available supply of scrap steel..."
\end{abstract}

-- Pennsylvania Energy Council

\subsection{Diesel Rationing}

Comments on rationing of diesel fuel were split between those who agreed with DOE that diesel rationing would be hard to enforce because of the substitutibility of other fuels, and those who felt that it was unfair to gasol ine-powered vehicle owners not to also ration diesel fuel.

Two major oil companies pointed out that allocation would probably be more effective than rationing in controlling diesel usage. One oil company stated that placing heating oil under an allocation system with a priority for home users would limit its transfer to diesel vehicle use. 
"There would be very little that could be done to prevent altermative fuels from getting into diesel highway vehicles. Allocation would probably, work better for parceiling out diesel than would rationing."

$$
\text { W a major oit company }
$$

The State of Washington Department of Licensing stated that it maintains a staff of field auditors to enforce $i$ ts fuel tax laws. These auditors have uncovered many instances (but not nearly a11) of tax evasion through the use of untaxed diesel fuel in highway vehicles. The Department offered to make this field staff available to DOE during rationing to act, in effect, as an investigatory arm of the government.

"Most fuel tax administrators have accepted the practical viewpoint that diesel fuel taxes are largely unenforceable. If a diesel fuel rationing program is dependent upon finding a method of preventing the diversion of nonrationed fue? to highway use, you con probably forget about rationing diesel fuel."

-- Washington Department of Licensing

\subsection{Unleaded Gasoline}

Comments were mixed on whether unleaded gasol ine should be treated differentiy than leaded gasoline during rationing.

We believe that unleaded and leaded gasoline are separate products and should be rationed as. separate products in order to ensure that each user receives its pro rata share."

$\because \cdots$

-- American Trucking Association 
"Since certain businesses, such as motor vehicle manufacturers, new car dealers, etc.", need a higher than average percentage of unleaded gasoline, MVMA recommends that the provisions of CFR 211.108(c)(1)(i) [of the current allocation regulations, relating to unleaded gasoline and new car dealers, et al.] be retained in the gasoline rationing program:"

-- Motor. Vehicle Manufacturers Association "There is no neossity for speoial treatment of unleaded
gasoline..."

- A major oil company

\subsection{Synthetic Gasoline}

A small number of comments advocated special treatment of synthetically produced gasoline.

"DOE [should] exempt from rationing synthetic gasoline derived from coal liquids (and possibly shale oil), and other gasoline alternatives such as biomass alcohol. Blends would bo exempted to the extenl they contain synthetic siels... It would create an incentive for the development of synfuels, with the producer able to comand a higher price in the marketplace to the extent synthetics cost less than white market coupons."

-a Aajor cautumobize marufacturer

\subsection{Ration Rights for Foreign Visitors}

States whose economies are dependent on tourism, and representatives of the travel industry, felt that some provisions should be made for providing foreign visitors with ration rights. 
"I think one area the plan ignores is provisions for supplying Canadian tourist's. A big percentage of the New Hompshire tourist economy is dependent on. Canadian tourism...

"I think the present plain does offer some possible solutions. For example, the white market has been one possible area that has been suggested to us for dealing with this problem. However, in my estimation, this alternative does not present itself as a viable solution.

"It's also been suggested that we allocate gasoline to these people out of the state ration reserve. That's something we don't have too much difficulty with but the fact that it was suggested that it would be a ration reserve of 3\% past use [sic] even though we feel that we could not meet our other emergency needs, if we were to supply these people out of that reserve. So: if the reserve was to be increased and we would consider supplying Canadian tourists with it, we wouldn't have any difficulty."

-- New Hampshire Governor's Council on Energy 
DEPARTMENT OF ENERGY: PUBLIC COMMENT CLASSIFICATION FORM PROPOSED STANDBY RATIONING PLAN

NUMBER

DATE CLASSIFIED

RESPONDENT NAME:

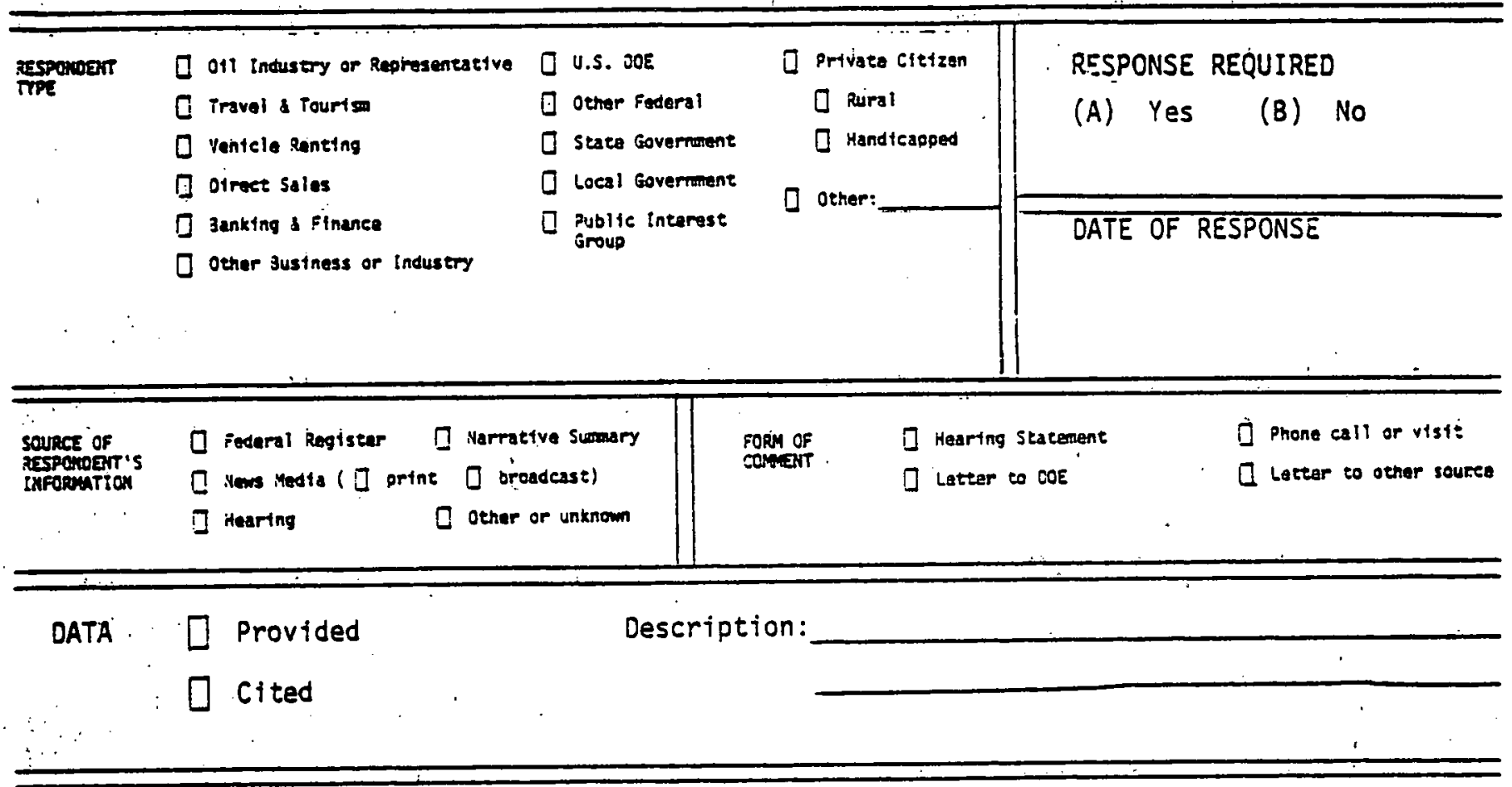

1. OVERVIEN

$\begin{array}{llllll}1.1 & \text { A } & \text { B } & & \\ 1.2 & \text { A } & \text { B } & & \\ 1.3 & \text { A } & \text { B } & \text { C } & \text { D }\end{array}$

2. THE TREATMENT OF INDIVIDUALS
2.1 A $B$ C
$2.2 A \quad B$
$\begin{array}{lllll}2.3 & A & B & C & 0 \\ & & E & F & G\end{array}$
$2.4: A \quad B$
$2.5 \mathrm{~A} \quad \mathrm{~B}$

3. THE TREATMENT OF FIRMS

3.1 A B C

$3.2 A \quad 8 \quad C \quad D$

3.3 A $B$ C $D$ E $F G$

$3.4 \mathrm{~A} \quad \mathrm{~B}$

4. ALLOCATION AND OISTRIBUTION OF GASOLINE

4.1 A B C

$4.2 \mathrm{~A} B$

4.3 A B

4.4 A
5. STATES

5.1 A 8 C

$5.2 A$

5.3 A B $C$

5.4 A B C

6. THE WHITE MARKET
6.1 A B C
6.2 A $B$
$6.3^{\circ}$ A B C
6.4 A $B$

7. MISCELLANEOUS

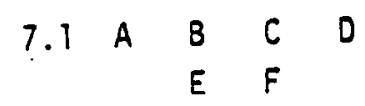


OIRECTIONS: Please check appropriate response(s). More than one response per question may be checked.

\section{OVERVIEW}

1.1 Overall response:
(A) positive
(8) negative

1.2 The proposed rationing plan:
(A) could work as is
(8) could work, but only with major changes

i.3 When should gasoline rationing be used:
(A) naver
(8) as a means of encouraging conservation under nonemergency conditions
(C) only in the event of a severe supply interruption
(D) only aftẹr alțęrnative messures have been triad (nompiẹte hel hw)

2. THE TREATMENT OF INDIVIDUALS

2.1 Individuals should receive allotments based on:
(A) licenses
(B). registration
(C) other (complete below)

2.2 A standard vehiele allotment:

(A) discriminates for or against specific groups

(B) is fair and equitable

2.3 The following group(s) should got additional ration rights;
(A) rural residents
B people who have long commutes
(C) people traveling
(E) migrant workers
(D) foreign visitors
(F) persons engaged in household moves
(a) others (complete bolow)

2.4 Adjusting allotments to reflect vehicle size and fuel efficiency:
(A) takes need into account
(B) unfairiy penalizes fuel efficiency

2.5 Recreational Vehicles (RVs) should:
(A) receive allotment index of 1.0
(B) other (complete below) 
3. THE TREATMENT OF EIRMS

3.1 Firms should receive allotments based on:
(A) base period use
(3) registration
(c) other (complete below)

3.2 Priorlty firms should recaive allotments equal to:
(A) less than base' period
(C) 100\% of base period
(B) $100 \%$ current needs
(D) other (complete below)

3.3 The following firms should be added to the pricrity classiftcation:
(A) taxicabs
(B) highway maintenance vehicles
(C) energy producers
(o) transportation for the aged
(E) utility maintenance vehicles
(F) emergency road services
(G) other (complete below).

3.4 The criteria for "designated firms":

(A) should be in the regulations

(B) should only be defined looseiy in the regulations

4. ALLOCATION ANO DISTRIBUTION OF GASOLINE, *;

4.1. Under rationing, allocation should be:
(A) retained as modified in the regulations
(B) modified further
(C) discontinued

4.2 Setting a time limit for offers and acceptances of surplus product sold by suppliers to their base period customers would:
(A) place din undue burden on these parties
(B) improve the efficiency of the distribution system

4.3 The burden on service, stations:
(A) would be acceptable
(B) is exce$$
\therefore
$$

4.4 Comments on gasoline pricing:

(A) complete below 
5. STATES

5.1 A state adjustment factor:
(A) would minimize hardship
(B) be unfair
(C) be unnecessary

5.2 A stata adjustment factor should be based on:

(A) complete below

5.3 Hardship guidelines, beyond provision for the handicapped, for administration of the State Ration Reserve (SRR) should be:
(A) listed in the regulations
(B) suggested in the regularions
(C) left entirely to the states' discretion

5.4 The basic allotment of ration rights to the state and local governments:
(A) should be equal to base period use
(B) should be equal to current needs
(C) government vehicles should have a higher allotment index

\section{THE WHITE MARKET}

6.1 The white market for ration rights:
(A) is generally a good idea
(B) would not function smoothly
(C) would invite fraud and the ft of ration rights

6.2 The white market would be a good substitute for hardship allotments:
(A) agree
(B) disagree

6.3 The white market:
(A) favors the rich
(B) is fair to everyone
(C) unfairly favors vehicle owners who don't need all of their allotments

6.4 Travelers could not rely on the white market because:

(A) it would be too unstable

(B) it would be too expensive

\section{MISCELLANEOUS COMMENTS}

7.1 Comments on: (summarize comments below)
(A) ration banking
(B) diesel rationing
(C) ration period length and/or calculation
(D) allotments to federal govermment
(E) economic, regulatory, and environmental analysis
(F) other 
